\title{
Spelen, informatie en procedures
}

Citation for published version (APA):

Peters, H. J. M. (1997). Spelen, informatie en procedures. Universiteit Maastricht. https://doi.org/10.26481/spe.19971121hp

Document status and date:

Published: 21/11/1997

DOI:

10.26481/spe.19971121hp

Document Version:

Publisher's PDF, also known as Version of record

\section{Please check the document version of this publication:}

- A submitted manuscript is the version of the article upon submission and before peer-review. There can be important differences between the submitted version and the official published version of record.

People interested in the research are advised to contact the author for the final version of the publication, or visit the DOI to the publisher's website.

- The final author version and the galley proof are versions of the publication after peer review.

- The final published version features the final layout of the paper including the volume, issue and page numbers.

Link to publication

\footnotetext{
General rights rights.

- You may freely distribute the URL identifying the publication in the public portal. please follow below link for the End User Agreement:

www.umlib.nl/taverne-license

Take down policy

If you believe that this document breaches copyright please contact us at:

repository@maastrichtuniversity.nl

providing details and we will investigate your claim.
}

Copyright and moral rights for the publications made accessible in the public portal are retained by the authors and/or other copyright owners and it is a condition of accessing publications that users recognise and abide by the legal requirements associated with these

- Users may download and print one copy of any publication from the public portal for the purpose of private study or research.

- You may not further distribute the material or use it for any profit-making activity or commercial gain

If the publication is distributed under the terms of Article $25 \mathrm{fa}$ of the Dutch Copyright Act, indicated by the "Taverne" license above, 


\title{
Spelen, Informatie en Procedures
}

\author{
Rede \\ uitgesproken bij de aanvaarding van het ambt van \\ hoogleraar in de Kwantitatieve Economie aan de \\ Universiteit Maastricht op \\ vrijdag 21 november 1997 \\ door
}

Hans Peters 


\section{$P=164026754$
$\begin{aligned} & \text { Universitioltsbitiotheek } \\ & \text { Unirsersiteit Maastricht }\end{aligned}$}

Voor Nina en Remco

ISBN 90-9011150-6

NUGI 689 
Mijnheer de Rector Magnificus, Dames en Heren

\section{VOORWOORD}

In 1991 bestond de Rijksuniversiteit Limburg 15 jaar. Ook de Faculteit der Algemene Wetenschappen, waar ik toen werkzaam was, liet zich niet onbetuigd, en riep een lustrumcommissie in het leven met als taak het organiseren van een symposium. Aan deze faculteit waren wiskundigen, letterkundigen, filosofen, historici, en informatici verbonden, die ook allen binnen de lustrumcommissie vertegenwoordigd waren. Onze samenwerking resulteerde in een ééndaags symposium getiteld De Mathematisering van de Cultuur $\mathcal{E}$ de Cultuur van de Mathematisering. Volgens Dagblad de Limburger was de titel van dit symposium tot stand gekomen middels de methode van populaire omkering. Geïnspireerd door deze analyse gaf ik mijn eigen bijdrage de titel Het Spel van de Wiskunde 8 de Wiskunde van het Spel. Deze voordracht zou niet uitsluitend over speltheorie gaan, anders had ik kunnen volstaan met de helft van de titel, maar ook over de rol van de wiskunde. Het uiteindelijke resultaat was een inleiding in de speltheorie en haar toepassingen, voorzien van historische en filosofische kanttekeningen. Het is er indertijd niet van gekomen deze voordracht ook in definitieve vorm op schrift te stellen, en deze rede kunt $u$ beschouwen als een poging dat verzuim goed te maken.

Wat gaan we doen? Kort uitgedrukt: we maken géén vogelvlucht over een uitgestrekt gebied, maar een wandeling door een gedeelte ervan. De historie van het gebied zal onze aandacht hebben, en daarnaast zullen we het onder meer hebben over twee begrippen die een sleutelrol spelen, namelijk de begrippen informatie en procedure. Maar: we will cross those bridges when we get to them.

Het is bij een inaugurale rede gebruikelijk de eigen plaats en richting in het landschap te beschrijven: ik zal dat dan ook doen, maar pas aan het einde van de wandeling. Laten we echter beginnen bij het begin. 


\section{HET BEGIN}

Speltheorie is een betrekkelijk jonge wetenschap, en misschien is zelfs het grootste deel van de speltheorie-literatuur in pakweg de afgelopen tien tot vijftien jaren verschenen. Dit is een sophisticated guess; zo niet, dan was het mijn eerste empirische onderzoek geweest. Vele kolommen in zowel economische, sociaal-wetenschappelijke als wiskundige tijdschriften worden met speltheorie en toepassingen gevuld. Nasst het sedert 1971 bestaande tijdschrift International Joumal of Game Theory, is er in 1989 het tijdschrift Games and Economic Behavior bijgekomen. En de meeste boeken op het gebied van de speltheorie zijn na 1980 geschreven. Op een belangrijke oorzaak van deze hausse kom ik straks nog terug. Nu naar het begin.

\section{A.A. Cournot}

Als beginpunt van de speltheorie komen meerdere werken in aanmerking, die dan ook geregeld terugkeren in historische beschouwingen ${ }^{1}$. Wat de negentiende eeuw betreft zal ik mij beperken tot een tweetal. Het meest bekende daarvan is ongetwijfeld het werk Recherches sur les Principes Mathématiques de la Théorie des Richesses van A.A. Cournot uit 1838. Dit werk gaat onder meer over duopolie. Twee bedrijven bieden hetzelfde soort product aan: de marktprijs van dat product en dus de winsten van beide bedrijven hangen af van het totale aanbod. Er is sprake van een spelsituatie want de winst van elk bedrijf hangt ook af van het aanbod van het andere bedrijf. Er zijn op zijn minst drie redenen waarom deze keuze als beginpunt van de speltheorie gerechtvaardigd zou kunnen zijn. In de eerste plaats formuleerde Cournot als eerste een voorloper van het Nash-evenwicht, namelijk het Cournot-evenwicht, en hij deed dat expliciet als-wat in moderne termen heet-een niet-coöperatief evenwicht, met inbegrip van de argumentatie waarbij het ene bedrijf veronderstellingen doet over de strategie (aanbod) van het andere. In zo'n Cournot-evenwicht maximaliseert het aanbod van elk bedrijf diens winst, bij gegeven aanbod van het ander. In de tweede plaats heeft zijn werk betrekking op een maatschappelijk (in dit geval economisch) probleem, en past het zodoende in de geest van de Theory of Games and Economic Behavior van von Neumann \& Morgenstern, een werk dat nog uitvoerig aan de orde komt. En in de derde plaats beschouwde hij de wiskunde

\footnotetext{
'Zie bijvoorbeeld Dimand \& Dimand (1996).
} 
als de noodzakelijke taal om een precieze analyse te kunnen maken van de effecten van competitie. Ik geef het volgende citaat uit een Engelse vertaling (Cournot, 1838, p. 79):

Every one has a vague idea of the effects of competition. Theory should have attempted to render this idea more precise; and yet, for lack of regarding the question from the proper point of view, and for want of recourse to symbols (of which the use in this connection becomes indispensable), economic writers have not in the least improved on popular notions in this respect.

Dergelijke argumenten klinken ons nu vertrouwd in de oren, maar men dient hierbij te bedenken dat de wiskundige formalisering binnen de economie pas later begint, bij schrijvers als Walras, Jevons, en Edgeworth, en dat echte (in de zin van niet uitsluitend beschrijvende) toepassing van de wiskunde in de economie eigenlijk van nog recentere datum is.

\section{C.L. Dodgson}

Een andere vroege bijdrage tot de speltheorie is het werk The Principles of Parliamentary Representation uit 1884 van Charles Lutwidge Dodgson, beter bekend als Lewis Carroll, de schrijver van Alice's Adventures in Wonderland and Through the Looking Glass. Het navolgende citaat is gebaseerd op het werk van de Schotse econoom Duncan Black (1969) ${ }^{2}$ :

Lewis Carroll's booklet, The Principles of Parliamentary Representation, applies the technique of the two-person zero-sum game, which we usually associate with economic theory, to provide a theory of proportional representation and a theory of the apportionment of parliamentary seats. The entire reasoning of the booklet is expressed in quantitative terms, again on the basis of the twoperson zero-sum game and the maximin criterion. A few months after the booklet had been completed Carroll made a further application of game theory, this time using the coalition game, in a very tentative way, to find the most suitable set of candidates to represent a constituency in an election.

\footnotetext{
${ }^{2}$ Zie pag. 45 van McLean et al. (1996).
} 
Voor wie zich afvraagt wat parlementaire zetelverdeling te maken heeft met speltheorie en in het bijzonder een nulsomspel, dit werkt als volgt. Carroll ging uit van een tweepartijen-stelsel. Iedere partij beschikt over een bepaald aantal stemmen en kandidaten, en er is een vast aantal zetels beschikbaar. Een partij kan haar stemmen verdelen over haar kandidaten voor die zetels; uiteindelijk worden de kandidaten met het grootste aantal stemmen verkozen totdat alle zetels opgevuld zijn. De vraag is dan hoe een partij haar stemmen over haar kandidaten moet verdelen. Carroll geeft een wiskundige analyse van dit probleem ${ }^{3}$, overigens zonder te komen tot een algemene formulering en oplossing van zogenaamde nulsomspelen, waarvan dit een bijzonder geval is.

Uit het citaat wordt duidelijk dat het genoemde werk van Carroll aan de drie in verband met Cournot genoemde 'criteria' voldoet: er wordt een speltheoretisch concept ontwikkeld, het heeft betrekking op een maatschappelijk probleem, en het gebruikt de wiskunde als taal.

In dit korte bestek, en gebaseerd op een tweetal artikelen van vóór 1890, zijn reeds een aantal concepten genoemd die nu tot de basis van de speltheorie behoren: het Nash (niet-coöperatief, Cournot) evenwicht, nulsomspelen, en coalities. We maken nu een belangrijke stap, namelijk naar de persoon die algemeen als de grondlegger van de speltheorie gezien wordt.

\section{JOHANN VON NEUMANN}

In 1928 publiceerde de 24-jarige Johann von Neumann het artikel Zur Theorie der Gesellschaftsspiele. In dit artikel bewees von Neumann de minimax stelling voor twee-persoons nulsomspelen met eindig veel zuivere strategieën. Voor de ingewijde zowel als de niet ingewijde lezer is dit algebra, dus laat ik een eenvoudig voorbeeld geven. Zo'n voorbeeld van een twee-persoons nulsomspel is het spel Matching Pennies. Twee spelers $A$ en $B$, laten ieder, gelijktijdig en onafhankelijk van elkaar, een gulden zien. Wanneer ze allebei 'kop' of allebei 'munt' laten zien zijn beide guldens voor speler $A$, anders voor speler $B$. Veronderstel dat beide spelers voor zichzelf een kans vaststellen waarmee ze 'kop' of 'rnunt' kiezen. In speltheoretische termen: beide spelers spelen een gemengde strategie. Het is niet moeilijk uit te rekenen dat

\footnotetext{
${ }^{3}$ Zie McLean et al. (1996), Part 2.

"Von Neumann had toen al zeventien wiskundige artikelen op zijn naam staan.
} 
speler $A$ in verwachting 0 kan krijgen ongeacht wat speler $B$ doet, namelijk door 'kop' en 'munt' met gelijke kans te kiezen, en dat dit ook geldt voor speler $B$. De (verwachte) uitbetaling 0 is daarmee de natuurlijke oplossing van dit spel: beide spelers kunnen zich die uitbetaling garanderen, er 'zit niets tussen'. Von Neumann bewees dat zo'n natuurlijke oplossing altijd (dat wil zeggen in alle mogelijke andere spelen van dit type) bestaat, dat wil zeggen een uitbetaling die beide spelers zich kunnen garanderen; bovendien kan deze uitbetaling bereikt worden door 'optimale' strategieën, waarbij het niet uitmaakt wat de tegenstander zal doen.

Waarom is, in tegenstelling tot het niet bijster opwindende voorbeeld, het resultaat wel verrassend? Laten we de terminologie overnemen waarbij speler $B$ aan speler $A$ betaalt. ${ }^{5}$ Het is logisch en ook semantisch gezien onmiddellijk duidelijk dat het bedrag dat speler $A$ zich in een nulsomspelspel kan garanderen, niet groter kan zijn dan het bedrag dat speler $B$ kan garanderen maximaal te moeten betalen. Je zou wel kunnen verwachten dat het echt kleiner is, dus dat er tussen wat de spelers zich kunnen garanderen een speling zit waarbinnen de oplossing van het spel terecht komt, afhankelijk van de combinatie van de gespeelde strategieën. 6 De Franse wiskundige Emile Borel (1927) bijvoorbeeld dacht inderdaad dat dit mogelijk zou kunnen zijn, ondanks het feit dat hij voor een aantal speciale gevallen het tegendeel al bewezen had. De minimax stelling zegt precies dat dit niet mogelijk is.

Ik ben hier vrij uitvoerig op ingegaan omdat dit resultaat een van de eerste toepassingen van de wiskunde binnen de economie is waaruit blijkt, dat de wiskunde meer te bieden heeft dan de bevestiging van 'a vague idea'-als ik even teruggrijp naar het citaat van Cournot. ' Inderdaad zou het belang van

\footnotetext{
'Zo'n betaling kan ook negatief zijn, betgeen de facto betekent dat speler $A$ aan $B$ betaalt.

6Von Neumann \& Morgenstern (1980, p. 35) noemen deze 'speling' ook wel 'zone of uncertainty'.

${ }^{7}$ Overigens illustreert een vergelijking van het door von Neumann gegeven oorspronkelijke bewijs met de huidige bewijzen van de minimax stelling op treffende wijze het dynamische karakter van de wiskunde, ook daar waar het gaat om eenmaal bereikte resultaten. In het oorspronkelijke bewijs van von Neumann spelen zowrel topologische als algebraïsche noties een rol. Tegenwoordig wordt het resultaat als equivalent beschouwd met de Dualiteitsstelling van Linesir Programmeren of Farkas' Lemma. Dit laatste heeft een duidelijke geometrische interpretatie, en kan algebraïsch bewezen worden, maar ook afgeleid worden uit de meest eenvoudige convexe scheidingsstelling, namelijk scheiding
} 
wiskundige formalisering van economische theorie beperkt blijven als daardoor niet ook additionele inzichten verkregen konden worden.

Nulsomspelen kunnen toegepast worden daar waar de belangen van de (twee) spelers strict tegengesteld zijn. Het parlementaire representatie-spel van Lewis Carroll was een voorbeeld (als de ene partij méér zetels krijgt, heeft de andere er vanzelf minder), maar in het algemeen heeft de nulsomspel-theorie minder toepassingen dan de theorie der niet-nulsomspelen. ${ }^{8}$ Zoals de titel van het artikel van von Neumann al aangeeft heeft de theorie ook betrekking op 'gezelschapsspelen' als kaarten, dammen en schaken. De minimax stelling is op bijvoorbeeld schaken van toepassing, hoewel een schaker voor zijn spel weinig baat zal hebben bij lezing van het artikel van von Neumann. ${ }^{9}$ In ieder geval betekent het Duitse woord Gesellschaft behalve gezelschap ook maatschappij, en daarmee loopt de titel van von Neumanns artikel vooruit op die van het eerste standaardwerk binnen de speltheorie: Theory of Games and Economic Behavior van (inmiddels) John von Neumann \& Oskar Morgenstern, voor het eerst verschenen in 1944.

\section{THEORY OF GAMES AND ECONOMIC BEHAVIOR}

Ook bij dit werk, dat ik kortheidshalve de Theory zal noemen, sta ik iets langer stil, niet alleen omdat het het eerste standaardwerk binnen de speltheorie is, maar ook om enkele andere redenen.

\section{Rol van de wiskunde}

In de eerste plaats geven de auteurs blijk van een hartverwarmend vertrouwen in de vooruitgang van de economische wetenschap. Hoofdstuk I van het boek, getiteld Formulation of the Economic Problem, is een (niet-technische) inleiding over het belang van de wiskunde voor de economie, en Paragraaf 1 van

van een convexe verzameling en een punt. De laatste stelling, op haar beurt, is gebaseerd op de stelling van Weierstrass-een continue functie op een compacte verzameling neent een maximum aan. De minimax stelling kan ook bewezen worden met behulp van de dekpuntstelling van Brouwer, maar dat werktuig is weer van een zwaardere categorie.

${ }^{8}$ Soms echter kom je toepassingen tegen in onverwachte hoeken. Zo las ik laatst een artikel over DEA, Data Envelopment Analysis, waarin nulsomspeltheorie werd toegepast. Zie Banker et al. (1989).

${ }^{9}$ Net zomin zal hij iets hebben aan het door de logicus Zermelo eerder, in 1913, bewezen resultaat dat in een spel als schaken of wit een winnende strategie heeft, óf zwart, óf beide partijen remise kunnen afdwingen. 
dat hoofdstuk gaat over The Mathematical Method in Economics in het algemeen. Als belangrijkste argumenten voor het gebruik van de wiskunde in de economische wetenschap worden genoemd het feit dat wiskundige formuleringen nopen tot precieze verbale, 'literaire' beschrijvingen van economische begrippen en dus tot precisie in het denken over economische problemen ${ }^{10}$; voorts het feit dat toepassing van wiskundige technieken tot inzichten kan leiden die niet bij voorbaat bekend of 'intuïtief' zijn. Een voorbeeld daarvan is de minimax stelling voor nulsomspelen, zoals we eerder al betoogd hebben. Bedenk daarbij dat in de veertiger jaren de 'mathematisering' van het economische denken eigenlijk nog moest beginnen. ${ }^{11}$ Het is wellicht een hart onder de riem van economen dat von Neumann en Morgenstern meer dan eens opmerken dat economie eigenlijk veel moeilijker is dan natuurkunde - onder meer oradat het veel moeilijker is de juiste begrippen te vinden en af te bakenen. ${ }^{12}$ Dit mag enigszins overdreven lijken, maar toch is het niet $z 0$ gemakkelijk echt fundamentele verschillen in karakter tussen beide wetenschappen aan te geven. Eén belangrijk criterium voor het succes van een wetenschap bijvoorbeeld, haar voorspellende vermogen, is ook in de natuurkunde geen vanzelfsprekende zaak. Zo kennen we alle wetten die een eenvoudige gebeurtenis als het laten vallen van een vel papier beheersen, maar zijn we niet in staat de plaats van landing met enige precisie te voorspellen. ${ }^{13}$

\section{Coöperatieve en niet-coöperatieve speltheorie}

In de tweede plaats wordt een basis gelegd voor het veel gemaakte onderscheid tussen coöperatieve en niet-coöperatieve speltheorie. In de niet-coöperatieve speltheorie, zoals de theorie der nulsomspelen, kunnen geen bindende afspraken tussen de spelers gemaakt worden. Het centrale begrip is het be-

\footnotetext{
${ }^{10}$ Men kan zich hier de wiskunde voorstellen als een strenge schoolneester die de arme leerling economie onder de knoet tracht te brengen. Als verzachtende omstandigheid kan echter aangevoerd worden dat deze schoolmeester niet zo lang dasrvoor zelf van deze beker heeft moeten drinken. Lakatos' (1976) Proofs and Refutations handelt over de 'foute' bewijzen van de formule $V-E+F=2$ van Euler, die het verband angeeft tussen het santal hoekpunten, ribben en vlakken van een polyheder; 'fouten', van wiskundigen als Euler en Cauchy, die meestal te wijten zijn asn gebrekkige definities.

"Ook de eerste rigoreuze wiskundige resultaten binnen de algemene evenwichtstheorie stammen uit deze periode en het begin van de vijftiger jaren.

${ }^{12}$ Argumenten van deze aard zouden op VWO-scholen kunnen worden verbreid, teneinde de keuze voor exacte richtingen te vergroten.

${ }^{13}$ Voorbeeld van Hugo Sonnenschein.
} 
grip strategie. In de coöperatieve speltheorie kunnen wel bindende afspraken tussen spelers in een coalitie gemaakt worden. De theorie is abstracter in die zin dat afgezien wordt van een precieze beschrijving van de strategieën. De centrale begrippen zijn coalities en uitbetalinger. In de Theory worden eigenlijk alleen twee-persoons nulsomspelen opgelost, gebaseerd op de minimax stelling, dus op het artikel van von Neumann uit 1928. Alle andere spelen-meerpersoons nulsomspelen en niet-nulsomspelen zoals het Cournot duopolie-worden omgezet naar een coöperatief coalitiespel. Zo'n coalitiespel wordt gedefinieerd door iedere mogelijke coalitie (dat wil zeggen deelverzameling van de spelers) een waarde te geven, een getal dat uitdrukt wat die coalitie met zekerheid zou kunnen bereiken, onafhankelijk van de andere spelers. In de Theory wordt die waarde gedefinieerd door, naar analogie van nulsomspelen, te veronderstellen dat de spelers in een coalitie een maximin combinatie van individuele strategieën afspreken, zeg maar een worst case scenario. Overigens dient hierbij opgemerkt te worden dat von Neumann \& Morgenstern het onderscheid tussen coöperatieve en niet-coöperatieve spelen niet echt maken. Zij beschouwen het geheel als één theorie.

\section{De stabiele verzameling}

In de derde plaats, en in het verlengde van het voorgaande, wordt in de Theory de 'natuurlijke' oplossing voor twee-persoons nulsomspelen, zoals boven geillustreerd voor het spel Matching Pennies, uitgebreid naar algemene coajitiespelen. De naam van dat uitgebreide oplossingsconcept is stabiele verzameling (stable set). Het gaat in dit bestek te ver om een precieze definitie te geven. Laat ik volstaan met op te merken dat verondersteld wordt dat de grote coalitie zich vormt, hetgeen wil zeggen dat alle spelers samenwerken. Een stabiele verzameling is dan een verzameling van mogelijke verdelingen van de waarde van die grote coalitie onder de spelers die elkaar onderling niet domineren-geen enkele coalitie wil en tegelijkertijd kan de ene verdeling boven een andere afdwingen-maar die wel de verdelingen buiten de verzameling domineren. ${ }^{14}$ Het grootste nadeel van dit concept is dat een stabiele verzameling (inderdaad) stabiel is als verzameling. Dat houdt in dat de stabiliteitseigenschap in principe niet overgaat op de afzonderlijke verdelingen binnen de verzameling. Voor het Cournot-duopolie bijvoorbeeld

\footnotetext{
${ }^{14}$ Dat wil zeggen: voor elke verdeling buiten de stabiele verzameling is er wel een coalitie te vinden die een verdeling binnen de verzameling wil en kan afdwingen.
} 
(wanneer we veronderstellen dat beide bedrijven samenwerken, dus een kartel vormen) is de enige stabjele verzameling simpelweg de verzameling van alle individueel rationele en efficiënte winstcombinaties: dus dat schiet niet erg op. ${ }^{15}$ Om dezelfde reden overigens is dit concept wel geschikt om sociale situaties te beschrijven die gekenmerkt worden door een stabiel geheel van dominanties. Dit idee is aanzienlijk veel later toegepast door Greenberg in zijn boek The Theory of Social Situations (Greenberg, 1990). Uit dit werk blijkt bovendien dat vele geaccepteerde oplossingsconcepten in de speltheorie gezien kunnen worden als stabiele verzamelingen in een geschikt geformuleerde sociale situatie. ${ }^{16}$ Voorts kan de stabiele verzameling beschouwd worden als voorloper van de core, een concept dat op basis van dezelfde dominantierelatie gedefinieerd kan worden. Dit concept werd voor coalitiespelen pas geformaliseerd door Gillies (1953).

\section{Verwacht nut}

Een laatste belangrijk element van de Theory is het gebruik van cardinale nutsfuncties of, preciezer, van verwachte-nutsfuncties. ${ }^{17}$ Dergelijke nutsfuncties zijn uniek op een stijgende lineaire transformatie na. Minder technisch uitgedrukt betekent dit dat nutsverschillen (voor één en hetzelfde individu) een rol spelen. Bij wijze van voorbeeld, als een appel voor mij nut 6 heeft en een peer 4 , dan betekent dat niet alleen dat ik liever een appel dan een peer heb, maar ook dat de intensiteit van deze voorkeur uitgedrukt wordt door het verschil van 2. Von Neumann \& Morgenstern besteden veel aandacht aan een rechtvaardiging van deze keuze ${ }^{18}$, hetgeen begrijpelijk is gezien de toen door de meeste economen geaccepteerde zienswijze dat nut slechts ordinaal kon zijn, dat wil zeggen uniek bepaald op een monotoon stijgende transformatie na, zodat nutsverschillen geen betekenis hebben. Dit hield in dat economische analyse diende plaats te vinden op basis van indifferentiecurves. Toch

\footnotetext{
${ }^{15}$ Er zijn nog andere nadelen. Een stabiele verzameling zelf is in het algemeen niet uniek: en coalitiespel kan vele stabiele verzamelingen bezitten. Ook lost de stabiele verzameling het existentieprobleern-door von Neumann \& Morgenstern als zeer belangrijk beschouwd-niet op, al bestaat zij wel in vele gevallen en heeft het 25 jaar geduurd eer Lucas met een voorbeeld van een coalitiespel kwam dat geen stabiele verzaraeling had. Zie Lucas (1969).

${ }^{16}$ Zie ook het recente werk van Delver en Monsuur (1997).

${ }^{17}$ Nutsfuncties geven de voorkeuren van de spelers getalsmatig weer.

${ }^{18} \mathrm{Zie}$, in de uitgave van 1980 , blz. $15-31$.
} 
was het Pareto (1907, p. 264) die vond dat het voldoende was transformaties toe te laten die de nutsverschillen gelijk houden. Deze visie was echter een instrumentele die empirisch moeilijk te interpreteren viel. Von Neumann \& Morgenstern geven daarom een axiomatische onderbouwing van het gebruik van verwacht nut, welke in een Appendix bij de uitgave van 1947 precies uitgewerkt wordt. ${ }^{19}$ Het gebruik van verwachte-nutsfuncties alsmede de discussie daarover is altijd van belang geweest en nog steeds van belang voor de speltheorie. Grote delen van de speltheorie zijn in technische zin afhankelijk van het gebruik van verwacht nut of verwachte uitbetalingen, met name de theorieën waarin gemengde strategieën een rol spelen. Andere delen zijn er wel op gebaseerd maar eerder in termen van interpretatie, met overigens belangrijke gevolgen. ${ }^{20}$

Hiermee sluit ik de bespreking van de Theory of Games and Economic Behavior af. Men kan dit werk beschouwen als het begin, maar met evenveel recht als het einde van een periode. Immers, de basis van de nulsomspeltheorie is gelegd $^{21}$, coalitiespelen zijn ingevoerd alsmede een oplossingsconcept daarvoor, de stabiele verzameling. Merkwaardigerwijze echter bevat the Theory geen enkele directe verwijzing naar het werk van Cournot. $\mathrm{Nu}$ veel gebruikte oplossingsconcepten als Nash evenwicht, Nash onderhandelingsoplossing, Shapley waarde en core kwamen alle pas in de vijftiger jaren naar voren. De axiomatische methode, zo belangrijk in de wiskunde en ook in de speltheorie, werd door von Neumann \& Morgenstern gepropageerd en gebruikt, maar axioma's hebben in hun werk vaak eerder het karakter van definiërende elementen dan van formele vertalingen van spelinhoudelijke-

\footnotetext{
${ }^{19}$ Een vroege alternatieve axiomatische onderbouwing kan men vinden in Herstein \& Milnor (1953).

${ }^{20}$ Daarnasst is er al in een vroeg stadium onder meer door de Allais paradox (Allais, 1953) een controverse ontstaan over de veronderstelling van verwacht nut, die niet zozeer te maken had met de tegenstelling tussen ordinaal en cardinaal, dan wel met de psychologische interpretatie van het kansbegrip en het onderscheid tussen winst en verlies. Deze discussie is in een stroomversnelling gekomen door het werk van Kahneman \& Tversky (1979), hetgeen geresulteerd heeft en nog steeds resulteert in een collectie van 'niet-verwacht-nut'-theorieen. De consequenties van dergelijke theorieën voor de speltheorie en andere economische theorieën-bijvoorbeeld theorieën welke investeringsgedrag onderzoeken - worden momenteel op ruime schaal onderzocht.

${ }^{21}$ Latere toevoegingen zijn vooral te vinden in the Contributions to the Theory of Games I-IV, en in Advances in Game Theory: zie de referentielijst.
} 
dus gedragsinhoudelijke - postulaten. $^{22}$ Deze status krijgen axioma's in veel sterkere mate in het werk van Nash en Shapley, enkele jaren later.

\section{Operations research}

Alvorens de stap naar de vijftiger jaren en verder te zetten, zijn enige opmerkingen over de positie van de Theory binnen het wetenschappelijke landschap van die tijd op hun plaats. Allereerst stond dit werk niet alleen, maar paste het binnen ontwikkelingen in de Operations Research. ${ }^{23}$ Zoals al eerder opgemerkt kan de minimax stelling voor nulsomspelen beschouwd worden als equivalent met de Dualiteitsstelling van de Lineaire Programmering. De Simplexmethode, nog steeds de meest gebruikte methode om Lineaire Programma's op te lossen, stamt uit deze periode. ${ }^{24}$ De term Operations Research is afkomstig uit de militaire wereld, en inderdaad heeft de Tweede Wereldoorlog een grote stimulans gegeven aan ontwikkelingen in de Operations Research. Ook de speltheorie kent, niet verwonderlijk, talrijke voorlopers in de militaire literatuur, zoals het twee milennia oude werk The Art of War van Sun Tzu of, dichter bij huis, de Colonel Blotto spelen (Borel, 1938). ${ }^{25}$ Ten tweede is het interessant op te merken dat de Operations Research en de speltheorie tot de eerste wiskundige disciplines behoren welke geinspireerd zijn vanuit de sociale wetenschappen (in ruime zin beschouwd), en niet vanuit de exacte wetenschappen. De economische theorie steunde en steunt in het algemeen op wiskunde ontwikkeld voor de exacte wetenschappen. Het zou best kunnen dat de sociale wetenschappen als het ware hun eigen wiskunde nodig hebben, en dat de verdere ontwikkeling daarvan ook tot het succes van deze wetenschappen zal bijdragen.

\section{DE VIJFTIGER JAREN}

De ontwikkeling van de speltheorie in de vijftiger jaren is vooral het werk van wiskundigen geweest. Hiervoor zijn meerdere oorzaken aan te geven, maar ik beperk me tot een tweetal. Een eerste oorzaak is van praktische

\footnotetext{
${ }^{22}$ Dit geldt niet voor hun The Axiomatic Treatment of Utility, toegevoegd als Appendix aan de uitgave van 1947.

${ }^{23}$ Besliskunde is de Nederlandse door D. van Dantzig bedachte term.

${ }^{24}$ Zie George B. Dantzig (1951).

${ }^{25}$ Zie Dimand \& Dimand, 1996, Hoofdstuk 6 voor een uitgebreid overzicht en verwijzingen.
} 
aard. Speltheorie is, net als algemene evenwichtstheorie, een sterk wiskundige discipline. Een tweede oorzaak is inhoudelijk: de speltheorie was nog niet zover ontwikkeld dat zij toegepast kon worden op een breed veld van economische problemen. Sterker nog, binnen de economische wetenschap zelf wist men nog nauwelijks om te gaan met een aantal problemen die nu centraal staan-ik denk hierbij vooral aan de rol die informatie speelt in economische situaties.

\section{Informatie en Nash evenwicht}

Vanaf de vijftiger jaren gaat het begrip 'informatie' een centrale rol spelen in de speltheorie, of wellicht moeten we zeggen: het woord informatie, want het betekent niet altijd hetzelfde. Allereerst, of we nu naar het duopoliespel van Cournot, het stemspel van Carroll, of het spel 'matching pennies' kijken, er is steeds sprake van een intrinsiek informatieprobleem: de spelers weten van elkaar niet wat ze gaan doen. Speltheoreten noemen dat imperfecte informatie, en uiteindelijk kan ieder niet-coöperatief spel herleid worden tot zijn zgn. strategische vorm, waarin sprake is van imperfecte informatie. Cournot veronderstelde dat de spelers (bedrijven) veronderstellingen maken over elkanders strategieën, en daarop optimaal, dat wil zeggen winstof nutsmaximaliserend, reageren. Een evenuicht is dan bereikt als die veronderstellingen en reacties met elkaar in overeenstemming zijn. Dit idee werd door Nash (1951) gegeneraliseerd, en zo ontstond het centrale concept van de speltheorie: het Nash-evenwicht. In $1994 \mathrm{kreeg}$ Nash hiervoor de Nobelprijs voor Economie, samen met Selten, die verantwoordelijk is voor de meest toegepaste verfijning van het concept, de (deelspel)perfectie (Selten, 1965, 1975), en Harsanyi, die de basis gelegd heeft voor toepassing van het Nashevenwicht in spelen met onvolledige informatie (Harsanyi, 1967-68). ${ }^{26} 27$

\footnotetext{
${ }^{26}$ Het Nash-evenwicht generaliseert dus het Cournot-evenwicht, maar net zo goed de theorie der nulsomspelen. Het von Stackelberg-evenwicht voor een duopolie, naar voren gebracht in de dertiger jaren (von Stackelberg, 1934), is niets anders dan een deelspelperfect Nash evenwicht in het perfecte-informatie spel waarbij de leider de eerste zet doet en de volger daarop resgeert.

${ }^{27} \mathrm{Het}$ Nash-evenwicht is gebaseerd op het idee van best ontwoord of beste reactie: in evenwicht reageert iedere speler optimaal op de strategie(ën) van zijn tegenstander(s). Een groot deel van de niet-coōperatieve speltheorie houdt zich bezig met verfijningen van het Nash evenwicht, zie van Damme (1991). Ook alternatieve concepten zoals rationalizeerbaarheid (zie Bernheir, 1984, en Pearce, 1984) en stabiliteit (Kohlberg \& Mertens,
} 


\section{Onvolledige informatie}

Met behulp van de gegeven definitie van (Nash of Cournot) evenwicht volgt dus dat voor iedere speler de strategieën van de andere spelers de 'beliefs' zijn van de betreffende speler over wat de anderen zullen doen, en dat de eigen strategie de optimale reactie daartegen is. In een Nash-evenwicht bevestigt het spelen van het spel de 'beliefs' die de spelers hadden. De overgang naar een tweede rol die het begrip informatie speelt in de speltheorie, is nu snel gemaakt. Dit is de rol van onvolledige informatie. Duopolisten kunnen onvolledige informatie hebben over elkaars technologie (bijvoorbeeld marginale kosten), stemmers over de voorkeuren van andere stemmmers, kaartspelers over welke kaarten de tegenstanders hebben. Het informatie-probleem is hier niet intrinsiek maar wordt veroorzaakt door externe factoren, die onafhankelijk zijn van het spelen van het spel zelf. Harsanyi modelleerde deze onvolledige informatie door het opnemen van een zet van de natuur, een kanszet dus. Alle informatie is belichaamd in het type van een speler, en iedere speler kent zijn eigen type maar heeft hooguit statistische informatie over de types van de andere spelers. (Bijvoorbeeld iedere kaartspeler kent zijn eigen kaarten en kan kansberekeningen uitvoeren over de kaarten van de andere spelers. Een bedrijf heeft statistische informatie over de kostenstructuur van de andere bedrijven.) De zet van de natuur kiest vooraf de types van de agenten. Door deze eenvoudige maar geniale vondst wordt onvolledige informatie gereduceerd tot imperfecte informatie, waarbij de spelers uitsluitend onzekerheid hebben over elkaars strategieën, en in hun 'beliefs' daarover de statistische informatie, belichaamd in de zet van de natuur, betrekken. ${ }^{28}$ Een agent kiest zijn strategie op basis van zijn eigen type en zijn 'belief' over wat de andere agenten zullen doen alsmede hun type. Er wordt dan ook in plaats van over Nash-evenwicht gesproken over Bayesiaans evenwicht. Overigens zit het nieuwe van de bijdrage van Harsanyi niet in het modelleren

1986; Vermeulen, 1996) zijn gebaseerd op het besto-antwoord concept. Het bestaan van een Nash evenwicht is in het algemeen geen probleern. In navolging van Nash (1951) kan voor spelen met eindig veel zuivere strategieën de existentie van een evenwicht in gemengde strategieen bewezen worden met de dekpuntstelling van Brouwer of Kakutani. Ook in andere gevallen wordt existentie met behulp van een dekpuntstelling bewezen. Een groot probleem vormt in het algemeen de multipliciteit van het Nash evenwicht, vandaar de grote nadruk in de literatuur op verfijningen.

${ }^{28}$ Het werk van Harsanyi is later in wiskundige zin vervolmaakt door Mertens \& Zamir (1985). 
van onvolledige informatie op zichzelf, maar in de wijze van modelleren van asymmetrische informatie. De ontwikkeling in de speltheorie loopt hier parallel aan ontwikkelingen in de economische theorie. Daar kom ik straks nog uitvoerig op terug.

\section{Procedure en Nash-onderhandelingsoplossing}

Middels de begrippen 'informatie' en 'Nash-evenwicht' zijn we de vijftiger en zelfs zestiger jaren ingegleden. Het derde begrip in de titel van deze oratie, het begrip 'procedure' zal ik inleiden naar aanleiding van de bespreking van een tweede belangrijke bijdrage uit de vijftiger jaren, de Nash-onderhandelingsoplossing, naar voren gebracht door Nash (1950) als oplossing voor het twee-persoonsonderhandelingsprobleem. Dit laatste is zowat het meest elementaire verdelingsprobleem dat men zich kan voorstellen. $\mathrm{Er}$ is een verzameling alternatieven, gerepresenteerd door hun nutten voor twee agenten, die over één dezer alternatieven overeenstemming trachten te bereiken. Indien dit niet lukt, volgt een vooraf bepaald dreig- of 'status quo' alternatief als resultaat. De Nash-oplossing selecteert dat alternatief waarin het product van de nutsverschillen met het dreig-alternatief voor beide agenten gemaximaliseerd wordt. De Nash-oplossing is binnen de speltheorie een van de meest bestudeerde, en bij toepassingen een van de meest gebruikte oplossingsconcepten. Hoe is deze populariteit te verklaren? In de eerste plaats is het een oplossing voor een probleem dat zich veelvuldig voordoet. Het duopoliemodel van Cournot is een voorbeeld wanneer we veronderstellen dat beide firma's samenwerken. Een ander veelvuldig bestudeerd voorbeeld zijn loon- en werkgelegenheidsonderhandelingen tussen werkgever en vakbond. ${ }^{29}{ }^{30}$ In de tweede plaats zou men een dik boekwerk kunnen vullen met alle verschillende onderbouwingen van deze eenvoudige oplossing. ${ }^{31}$ Deze veelheid heeft ongetwijfeld te maken met de elementaire wiskundige vorm van de Nash onderhandelingsoplossing. ${ }^{32}$ Nash (1950) gaf een axiomatische onderbouwing van deze oplossing, dat wil zeggen hij formuleerde een aantal eigenschappen waaraan een goede oplossing zou moeten voldoen, en liet vervolgens zien dat deze oplossing de enige was met al deze eigenschappen.

\footnotetext{
${ }^{29}$ Zie bijvoor beeld McDonald \& Solow (1981).

${ }^{30}$ Nash (1950) zelf had als voorbeeld de verdeling van speelgoed tussen twee jongens.

${ }^{31}$ Zie bijvoorbeeld Peters (1992).

${ }^{32}$ Als kritische noot dient opgemerkt te worden dat bij de meeste toepassingen van het concept dergelijke onderbouwingen nawwelijks gebruikt worden.
} 
Een dergelijke benadering kan men zien als beschrijvend van wat er aan de onderhandelingstafel gebeurt, maar meer voor de hand ligt haar te zien als voorschrijvend van wat er zou moeten gebeuren. Bij die laatste interpretatie doen zich echter twee problemen voor: wie heeft het gezag om een oplossing voor te schrijven, en, zo er al een autoriteit is, hoe komt deze aan de benodigde informatie (bijvoorbeeld over de voorkeuren of nutsfuncties van de agenten)? Nash zelf was zich van deze problematiek bewrist en stelde (in een artikel in 1953) een bijbehorend niet-coöperatief spel voor waarvan de evenwichten (op een weliswaar enigszins gekunstelde manier) leidden tot de Nash-oplossing van het bijbehorende onderhandelingsprobleem. In deze context kunnen we de Nash-onderhandelingsoplossing zien als een centrale procedure waarin het daartoe bevoegd gezag de data van het probleem stopt en er een oplossing uitrolt. De eerder gesignaleerde problemen kunnen dan worden benaderd door het ontwerpen van een decentrale procedure waarvoor de betrokken partijen (in dit geval de onderhandelaars) zelf de informatie of strategische keuzen aanreiken. Voor het onderhandelingsprobleem is de meest bekende en elegante procedure het Rubinstein 'alternating offers' model met tijdverdiscontering, waarvan de unieke uitbetalingen verkrijgbaar in een deelspel-perfect Nash-evenwicht convergeren naar de Nash-onderhandelingsoplossing. ${ }^{33}$ Minder technisch uitgedrukt: de spelers doen zelf voorstellen, en in evenwicht wordt hiermee de Nash-onderhandelingsoplossing benaderd. Er is dus geen autoriteit nodig die de macht en de informatie bezit.

Hiermee hebben we niet alleen de Nash-onderhandelingsoplossing besproken, maar tevens de algemenere begrippen centrale en decentrale procedure aan de orde gesteld. Zo'n decentrale procedure is dus een generalisatie van een niet-coöperatief, strategisch spel. Strategieën kunnen daarbij geheel of gedeeltelijk uit informatie bestaan, het onderscheid is niet altijd scherp. Bij verkiezingen bijvoorbeeld hebben stemmen zowel een strategische als een zuiver informatieve betekenis; ze geven de voorkeuren van de stemmers, maar deze kunnen strategisch gebruikt worden. De taak van de spelthe-

\footnotetext{
${ }^{33}$ Zie Rubinstein (1982). Overigens is de relatie met de Nash-oplossing pas later opgemerkt: zie Binmore \& Dasgupta (1987). Naar aanleiding van het artikel van Nash uit 1953 wordt het streven warbij coöperatieve oplossingen-zoals de Nashonderhandelingsoplossing -ondersteund worden door niet-coöperatieve procedures wel het Nash programma genoemd.
} 
orie is tweeledig: niet alleen de analyse van centrale procedures-waartoe ook de bestudering van het Nash-evenwichtsconcept behoort-maar tevens (en daarmee nauw samenhangend) het ontwerp van decentrale procedures. ${ }^{34}$ Hierbij kan het gaan over onderhandelingsprocedures, verkiezingssystemen, budgetteer- en allocatiemechanismen, faillissementsprocedures, en vele andere. Ook hierop komen we verderop nog terug. ${ }^{35}$

Naast het Nash-evenwicht en de Nash-onderhandelingsoplossing is er nog een tweetal oplossingsconcepten uit de vijftiger jaren dat $i k$ hier niet onbesproken wil laten: de Shapley-waarde en de core.

\section{Shapley waarde}

De Shapley waande (Shapley, 1953) is een oplossingsconcept dat voor elk coalitiespel een verdeling van de waarde van de grote coalitie tussen de spelers bepaalt. De veronderstelling is ook hier, net als bij de stabiele verzameling van von Neumann \& Morgenstern, dat die grote coalitie gevormd wordt. Net als de Nash-onderhandelingsoplossing wordt de Shapley waarde gegeven door een relatief eenvoudige formule, hetgeen wellicht het grote aantal axiomatische karakteriseringen verklaart. ${ }^{36}$ Stelt u zich voor dat de grote coalitie gevormd wordt, en laat het lot een speler aanwijzen. Laat vervolgens die speler vertrekken onder medeneming van zijn marginale bijdrage, dat wil zeggen het verschil tussen de warde van de grote coalitie en de waarde van de coalitie die ontstaat als die speler vertrekt. Laat het lot vervolgens een speler aanwijzen in de achterblijvende coalitie, en laat deze weer vertrekken met zijn marginale bijdrage aan die coalitie. Dit gaat zo door totdat alle spelers vertrokken zijn. De Shapley waarde is die verdeling waarin iedere speler zijn verwachte marginale bijdrage krijgt, waarbij de verwachting genomen

\footnotetext{
${ }^{34}$ Ik vermijd hier de in het wetenschappelijk spraakgebruik min of meer bekende termen als mechanisme, implementatie, of spelvorm, ook omdat er nogal eens verwarring bestaat over de genoemde termen.

${ }^{35}$ Volgens de boven informeel ingevoerde terminologie is een niet-coöperatief spel een decentrale procedure, en het Nash evenwicht een centrale procedure ter oplossing van het spel. Hoe bereiken de spelers zo'n evenwicht? Op deze zeer belangrijke kwestie gaan we hier niet in. Het is een vraag die altijd al gespeeld heeft, zowel in de speltheorie zelf als in de economische theorie in het algemeen en in de algemene evenwichtstheorie in het bijzonder. Tegenwoordig wordt aan deze kwestie vooral aandacht besteed binnen de evolutionaire speltheorie en binnen leertheorieën, waarbij meestal wordt uitgegaan van beperkte rationaliteit.

${ }^{36}$ Zie bijvoorbeeld Peters \& Vrieze (1993).
} 
wordt over alle mogelijke volgordes van vertrek. Dit procédé kan met enige handigheid omgezet worden in een decentrale procedure waarvan de evenwichtsuitbetalingen overeenstemmen met de Shapley waarde van het spel. ${ }^{37}$

\section{Core}

De core, geïntroduceerd door Gillies (1953), had al door von Neumann \& Morgenstern ingevoerd kunnen zijn, maar dezen zijn een andere weg ingeslagen en kwamen uit bij de stabiele verzameling. ${ }^{38}$ In de core wordt er wederom van uitgegaan dat alle spelers samenwerken, en dat de waarde van de grote coalitie zodanig over de spelers verdeeld wordt dat in elke deelcoalitie de spelers samen minstens zoveel krijgen als de waarde van die deelcoalitie. Hoewel de core meestal gezien wordt als een coöperatief concept, is de onderliggende gedachte strategisch: coalities moeten niet willen 'afwijken'. ${ }^{39}$ In de meeste decentrale procedures die tot core-allocaties leiden blijkt dit ook; in bet algemeen corresponderen core-allocaties met uitbetalingen behorende bij zgn. sterke Nash evenwichten van de procedure, hetgeen betekent dat geen enkele coalitie er brat bij heeft af te wijken.

${ }^{37}$ Zie Gul (1989), en Hart \& Mas-Colell (1996).

${ }^{38}$ De core is gebaseerd op de overweging dat coalities bepaalde verdelingen kunnen blokkeren. Deze dominantie-relatie vinden we al in de Theory of Games and Economic Behavior. In een drie-persoons nulsomspel waarin alle twee-persoonscoalities de waarde 1 hebben is er voor elke verdeling van 0 over de drie spelers wel een coalitie te vinden welke die verdeling kan blokkeren (zie von Neumann \& Morgenstern, 1980, p. 39 ff.). Von Neumann \& Morgenstern hebben dit probleem opgelost door aan de oplossingsverzameling een verdeling toe te voegen die op haar beurt de blokkerende verdeling blokkeert. Zo ontstaat een stabiele verzameling. In de core gebeurt dit niet, maar neemt men genoegen met het feit dat de oplossingsverzameling in een voorbeeld als dit leeg is.

${ }^{39} \mathrm{De}$ core speelt een belangrijke rol in de algemene evenwichtstheorie. In het bijzonder bevinden zich Walras-allocaties altijd in de core, en zgn. core-equivalentie stellingen zeggen, grofweg, dat naarmate het aantal spelers of agenten in de economie op een bepaalde manier toeneemt, de core steeds kleines wordt en krimpt naar een Walras-allocatie. Dit inzicht kan overigens al bij Edgeworth (1881) aangetroffen worden. Een Walras-allocatie behoort bij een Walras-evenwicht; dit is weliswasr niet hetzelfde als een Nash-evenwicht, maar de begrippen kunnen met elkaar in verband gebracht worden, hetgeen eens te meer het strategische karakter van het core-concept aangeeft. Zie bijvoorbeeld Ellickson (1993) voor verdere uitleg en referenties. 


\section{ASYMMETRISCHE INFORMATIE}

In de economische theorievorming sedert de zestiger jaren neent de bestudering van onvolledige of beter asymmetrische informatie een centrale plaats in. Van asymmetrische informatie is sprake wanneer niet alle partijen of agenten dezelfde informatie hebben. De omvang van de literatuur op dit gebied, met name vanaf 1970 , is ontzagwekkend. Ook op gebieden waar economische theorievorming van oudsher minder uitgebreid was, heeft het voortschrijdende inzicht over de rol van informatie geleid tot meer theoretische diepgang. Met name de traditionele bedrijfseconomische disciplines hebben in dat opzicht een metamorfose ondergaan, en de afstand tot de meer formeeltheoretische disciplines als micro-economie en evenwichtstheorie is daarmee sterk verkleind en vaak verdwenen. In het bijzonder is de speltheorie een belangrijke rol gaan spelen.

\section{Akerlof}

Een van de eerste artikelen die zich bezighouden met asymmetrische informatie is het artikel van Akerlof (1970) over de markt voor tweedehands auto's. In vergelijking met de verkoper heeft de eventuele koper van een tweedehands auto minder of geen informatie over de kwaliteit van de auto, en is daarom niet bereid meer dan een gemiddelde prijs te betalen. Voor die prijs is de bezitter van een auto van goede kwaliteit echter niet bereid zijn wagen van de hand te doen. Dit gebrek aan marktefficiëntie is zuiver een gevolg van asymmetrische informatie. Merk op dat het bezit van informatie dus niet altijd voordeel oplevert. Deze situatie kan gezien worden als een spel met onvolledige informatie waarbij een kanszet eerst de kwaliteit van de auto bepaalt, vervolgens de hierover niet geïnformeerde potentïele koper een bod doet, en de geïnformeerde verkoper dit bod accepteert of niet.

\section{Rationaliteitscriterium van Spence}

In de praktijk kan de verkoper van de auto trachten een signaal af te geven over de kwaliteit ervan, bijvoorbeeld in de vorm van een garantie. Een minimale voorwaarde voor de geloofwaardigheid van zo'n signaal is dat de kosten ervan hoger moeten zijn naarmate de kwaliteit van de auto lager is-anders kan jedereen wel zo'n signaal afgeven. Bij het afgeven van een garantie is dit natuurlijk het geval. Dit idee vindt men voor het eerst bij Spence (1973), 
waar het niet gaat om goede of slechte auto's maar om bekwame of niet-bekwame sollicitanten voor een baan. Het bezit van een diploma is daarbij een signaal voor de bekwaamheid van de sollicitant, niet omdat deze iets geleerd heeft van de opleiding, maar omdat een bekwame sollicitant het diploma gemakkelijker haalt. In een evenwicht volgen bekwame sollicitanten de opleiding en halen het diploma, en onbekwame sollicanten doen dat niet omdat de prijs ervan niet opweegt tegen het later eventueel te verwerven hogere loon. De werkgever heeft een belief dat hiermee overeenstemt, en dat weer bevestigd wordt door de keuze van de sollicitanten. Dit wordt aangeduid als het rationaliteitscriterium van Spence.

\section{Signaleren}

Ook een dergelijke situatie geeft aanleiding tot een spel. Toegepast op de tweedehands-auto markt ziet dit er als volgt uit. De natuur kiest de kwaliteit van de auto, en de hierover geïnformeerde verkoper kiest tussen het al dan niet afgeven van een garantie. De niet over de kwaliteit geïnformeerde koper kiest vervolgens de prijs. Ook hier kan een evenwicht zijn dat garanties alleen afgegeven worden voor goede auto's, dat de koper dit gelooft en zijn prijs daarop afstemt, en dat dit geloof inderdaad door de praktijk bevestigd wordt. Dergelijke spelen heten om begrijpelijke redenen wel signaleringsspelen, en vormen wellicht de meest toegepaste klasse van spelen in de economische theorie. Zo zijn ze toegepast om aan te tonen dat de stelling van Modigliani en Miller, welke zegt dat in een perfecte markt de verhouding tussen vreemd en eigen vermogen ter financiering van een bedrijf er niet toe doet, niet geldig is wanneer er sprake is van asymmetrische informatie. Bij Ross (1977) bijvoorbeeld geeft de manager van een bedrijf voor potentiële investeerders een signaal af over de waarde van het bedrijf door zijn eigen beloning te koppelen aan het al of niet kunnen terugbetalen van het aangetrokken vreemd vermogen; het signaal is dan de onvang daarvan. ${ }^{40}$

\section{Sequentieel evenwicht}

De zo juist gegeven schets suggereert wellicht dat de genoemde artikelen in speltheoretische termen geschreven zijn. Dat is echter niet het geval. Het speltheoretische raamwerk geschikt voor de beschreven signaleringsmodellen

\footnotetext{
${ }^{40}$ Zie Thakor (1991) voor een overzicht van speltheoretische toepassingen binnen de financiering.
} 
is pas in de jaren tachtig verder ontwikkeld en gepubliceerd, hoewel de ingrediënten reeds eerder aanwezig waren, met name in het werk van Harsanyi. Een belangrijke ontwikkeling was de publicatie van het artikel van Kreps \& Wilson in 1982, waarin het zgn. sequentieel Nosh evenwicht voorgesteld werd. Dit is het belangrijkste evenwichtsconcept voor spelen met onvolledige informatie. Het rationaliteitscriterium van Spence wordt hier speltheoretisch geformaliseerd. In deze periode is het inzicht in spelen en situaties met onvolledige informatie sterk toegenomen en-om terug te grijpen naar het begin van mijn betoog- dit is ongetwijfeld een van de belangrijkste redenen geweest is voor de hoge vlucht die de speltheorie en vooral de toepassing ervan gedurende de afgelopen vijftien jaren genomen heeft.

\section{HET ONTWERP VAN PROCEDURES}

Vele van deze toepassingen hebben gemeen dat er niet uitsluitend oplossingen worden uitgerekend (zoals sequentiële evenwichten in de zo juist gegeven voorbeelden) maar dat ook het spel zelf ontworpen wordt. In het voorbeeld van Ross (1973) is het spel met name vastgelegd door keuze van een beloningsschema voor de manager; in het geval van de tweedehands-automarkt worden mogelijkheden als het verlenen van garanties aan het spel toegevoegd. Een andere klasse van spelen wordt geleverd door de principaal-agent theorie. Het standaardvoorbeeld is dat van een baas en zijn knecht. De baas kan de inspanning van zijn knecht niet observeren maar wel het resultaat. Dat resultaat hangt af van de inspanning van die knecht maar ook van andere factoren die aan kans onderhevig zijn (het weer, de markt). De baas bedenkt een beloningsschema dat de knecht ertoe aanzet zijn best te doen. Zo'n beloningsschema ontstaat in een spel met volledige en zelfs perfecte informatie warin een deelspel-perfect Nash evenwicht verondersteld wordt. Interessant is hier echter het ontwerp van het spel, met andere woorden van het type beloningsschems.

Algemener beschouwd, gaat het hier steeds om het ontwerpen van decentrale procedures. Eerder genoemde voorbeelden waren decentrale procedures waarin evenwichtsuitbetalingen iets te maken hadden met andere oplossingsconcepten als de Nash-onderhandelingsoplossing of de core. In die gevallen dienen de ontworpen procedures meestal ter decentralisatie van macht, niet zozeer van informatie. Neem de Nash-onderhandelingsoplossing. Uiter- 
aard kan men veronderstellen dat deze oplossing in een gegeven situatie het onderhandelingsresultaat beschrijft, en men kan dat empirisch toetsen. Men kan de oplossing ook normatief zien, en in het verlengde daarvan veronderstellen dat een bemiddelaar zijn bindend advies erop baseert. Wanneer echter daartoe de wettelijke mogelijkheden ontbreken, kan wellicht de Rubinsteinonderhandelingsprocedure voorgeschreven worden waarin de spelers in evenwicht toch (bij benadering) de Nash-uitkomst bereiken. In dit geval hoeft de centrale bemiddelaar (of theoreticus) weliswaar niet op de hoogte te zijn van de precieze onderhandelingsruimte, maar de spelers moeten die informatie wel hebben. Dit staat in zekere tegenstelling tot de boven genoemde voorbeelden uit de informatie-economie, waarbij informatie onvolledig en asymmetrisch is, maar wel in het spel (dat wil zeggen het spelen) geheel of gedeeltelijk onthuld kan worden.

\section{STRATEGY-PROOFNESS: DECENTRALISATIE VAN MACHT EN VAN INFORMATIE}

Het laatste inhoudelijke deel van mijn betoog gaat over procedures waarin zowel macht als informatie gedecentraliseerd worden: prototype hiervan is stemmen. Als voorbeeld nemen we het Eurovisie-songfestival, waarvan je meestal alleen de stemprocedure aan het eind onthoudt. Doel van deze procedure is te komen tot een eindrangschikking op basis van de individuele (in dit geval nationale) rangschikkingen. Waarom wordt hiervoor eigenlijk gestemd? Behalve dat dit het enige interessante deel van het programma is zijn er in ieder geval minstens twee andere redenen te noemen. In de eerste plaats zullen de meeste landen het er niet mee eens zijn dat één centrale persoon of comité de eindrangschikking bepaalt. In de tweede plaats, ook als zo'n centraal orgaan de voorkeuren van de verschillende landen in acht zou nemen, zou het die eerst moeten kennen. Decentralisatie van macht en informatie is dus gewenst.

Wanneer we het informatie-probleem eerst even terzijde laten liggen, is de vraag: hoe kunnen we de individuele voorkeuren aggregeren tot een groepsofwel eindvoorkeur? Bij het Eurovisiesongfestival worden door de verschillende landen punten toegekend, die vervolgens opgeteld worden en zodoende de eindrangschikking bepalen. Deze methode heeft een aantal duidelijke voordelen. Zij werkt altijd, wat de individuele rangschikkingen ook mo- 
gen zijn, en wanneer elk land de Nederlandse bijdrage beter vindt dan de IJslandse zal Nederland IJsland ook verslaan. De eindrangschikking hangt verder alleen af van de individuele rangschikkingen en niet van wie welke volgorde aangeeft. Zo zijn er nog wel meer voordelen te noemen. Er is echter ook een nadeel. Of Nederland IJsland verslaat hangt niet alleen af van de individuele voorkeuren ten aanzien van die twee bijdragen maar ook van de individuele rangschikkingen van de andere bijdragen. Dat kan pijnlijk zijn als Nederland op de eerste plaats eindigt en IJsland op de tweede, of omgekeerd. Gelukkig komt een dergelijke situatie niet vaak voor.

\section{Arrow}

Arrow heeft in 1951 al laten zien dat dit laatste probleem onvermijdelijk is, tenzij we een dictatuur accepteren (één land dicteert de uitslag) of niet alle mogelijke voorkeuren toelaatbaar achten. De eerste oplossing is niet aantrekkelijk. De laatste oplossing is echter niet altijd mogelijk, zie het Eurovisie-songfestival.

Soortgelijke problemen doen zich ook voor wanneer we het informatie-aspect in het spel betrekken. Bij het Eurovisiesongfestival namelijk kan de uitslag ten eigen voordele beïnvloed worden door strategisch te stemmen-zeg maar: niet je ware voorkeur op te geven-zeker aan het einde van de stemprocedure. Dat geen enkel land op zichzelf mag stemmen is slechts een zwakke poging hier iets tegen te doen. Ik beweer niet dat dergelijke manipulatie ook plaats vindt of gemakkelijk uit te voeren is, maar zij is mogelijk. Ook hier hebben we weer te doen met een probleem van algemene aard, zoals Gibbard (1973) en Satterthwaite (1975), en eerder Hurwicz (1972), hebben aangetoond.

\section{Niet-manipuleerbaarheid}

Algemeen geformuleerd, kunnen we de volgende vraag stellen: kunnen we procedures ontwerpen warbij agenten de juiste informatie verschaffen? Deze vraag is uiteraard niet alleen van belang voor het Eurovisiesongfestival, maar voor vele andere situaties, zoals het heffen van belastingen ${ }^{\mathbf{4}}$, het verdelen van budgetten, het ontwerp van veilingen ${ }^{42}$, enz. De vraag raakt aan een uitgestrekt wetenschapsgebied, maar ik wil mij hier beperken tot het werk van Gibbard en Satterthwaite en de daarop volgende literatuur. Deze literatuur

\footnotetext{
${ }^{41}$ Vergelijk het zgn. Clarke-Groves mechanisme, zie Clarke (1971) en Groves (1973).

42Vergelijk Vickrey (1961).
} 
betreft het ontwerpen van decentrale procedures waarbij de agenten of spelers om hun voorkeuren ten aanzien van een verzameling alternatieven gevraagd wordt (denk maar weer aan het Eurovisiesongfestival). Die voorkeuren zijn daarmee de mogelijke strategieën van de spelers in een spel, en wanneer we graag willen dat dezen hun ware voorkeuren opgeven moeten we dus een spel ontwerpen waarin deze ware voorkeuren dominante strategieën vormen. Dit laatste betekent dat het opgeven van de ware voorkeur (dus het verschaffen van de juiste informatie) altijd optimaal is, welke voorkeuren de andere spelers ook opgeven. Dit is veel sterker dan alleen maar te eisen dat de ware voorkeuren een Nash-evenwicht vormen, en het resultaat van Gibbard en Satterthwaite dat zegt dat in het algemeen (onder redelijke condities) dergelijke dominante strategieën niet bestaan is, zo beschouwd, dan ook niet verbazingwekkend. Een spel of procedure waarin de waarheid spreken wel dominant is, heet strategy-proof-waarbij het woord 'strategy' in pejoratieve zin gebruikt wordt-of niet-manipuleerbaar.

Alvorens hier verder op in te gaan, moeten we ons wellicht eerst afvragen waarom we eigenlijk zouden willen dat iedereen de waarheid spreekt, dus dat de juiste informatie boven tafel komt. Ethische overwegingen kunnen hier meespelen, maar zijn wellicht niet het belangrijkst. Bij verkiezingen bijvoorbeeld vinden we het niet onethisch dat een PvdA'er niet op de PvdA stemt maar op Groen Links om wat tegenwicht tegen Paars te geven-ik noem maar een voorbeeld. Belangrijker is dat manipulatie ertoe kan leiden dat beslissingen op basis van de onjuiste informatie genomen worden, en daardoor bijvoorbeeld niet efficiënt zijn-denk aan het free-rider probleem bij beslissingen omtrent openbare voorzieningen. Een tweede belangrijke reden is dat strategy-proofness het individuele beslisproces van elke agent vergemakkelijkt: men hoeft er immers niet naar te gissen wat de anderen zullen doen.

Voor het negatieve resultaat van Gibbard en Satterthwaite bestaan dezelfde oplossingen als voor dat van Arrow ${ }^{43}$. We kunnen dictatuur toestaan, maar dat is niet erg aantrekkelijk. We kunnen ook het aantal mogelijke voorkeuren beperken, en dat is in vele gevallen wel een redelijke oplossing. Bijvoorbeeld, wanneer een bepaald bedrag verdeeld moet worden over twee projecten, waarbij meerdere partijen daar iets over te zeggen hebben, is het niet onredelijk

\footnotetext{
${ }^{43}$ Gexien het feit dat beide resultaten logisch of wiskundig gezien praktisch equivalent zijn is dit niet verrassend.
} 
aan te nemen dat iedere betrokken partij een soort ideale verdeling voor ogen staat; hoe dichter de uiteindelijke verdeling van het geld deze ideale verdeling benadert, des te tevredener is de betreffende partij met het resultaat. Men kan dan iedere partij naar haar ideale verdeling vragen, en van alle opgegeven verdelingen de mediaan (de 'middelste' dus) nemen, even aannemend dat het aantal partijen oneven is. Deze procedure is niet-manipuleerbaar, anoniem, en efficiënt, en het is zelfs de enige met deze eigenschappen ${ }^{44}$. Dit voorbeeld staat model voor een grote hoeveelheid literatuur die in de afgelopen twintig jaren tot ontwikkeling is gekomen.

\section{WAT DOEN WIJ?}

Ik ben hiermee gekomen aan het einde van mijn wandeling. Zoals aan het begin al gezegd: de wandeling voerde door een beperkt deel van het landschap. Toch zijn belangrijke elementen: spelen, informatie, en procedures, ruimschoots aan bod gekomen. Dit is in overeenstemming met de communis opinio binnen de economie, als je de Nobelprijzen voor economie tenminste als uitdrukking daarvan mag beschouwen. In 1994 ging deze prijs naar Nash, Harsanyi, en Selten, voor hun werk in de (niet-coöperatieve) speltheorie, en in 1996 nar Mirrlees en Vickrey voor hun werk op het gebied van economie en informatie. Een van de volgende prijzen zou wellicht het thema coöperatie en informatie moeten afdekken, waarbij het ontwerpen van procedures, mechanism design, centraal staat, en aan het begin warrvan het werk van Leonid Hurwicz staat. ${ }^{45}$

Een van de zwartepunten van ons eigen werk ligt op dit gebied, in het bijzonder het thema niet-manipuleerbaarheid. Daarnaast hebben we de afgelopen jaren gewerkt op het gebied van de coöperatieve en de niet-coöperatieve speltheorie, onderhandelingstheorie, en toepassingen, zoals belastingharmonisatie en corporate governance. En voorts moeten ook wij onze steen bijdragen aan de deadweight loss in het kader van de zgn. wetenschapssturing. Robert Aumann ging er bij de conferentie ter gelegenheid van zijn 65ste verjaardag in 1995 prat op nog nooit van zijn leven een formulier ter zake

\footnotetext{
${ }^{14}$ Zie Moulin (1980). Anonimiteit betekent dat bet niet uitmaakt welke partij welke verdeling opgeeft, en efficiēntie betekent dat er nooit een verdeling zal zijn die voor alle partijen beter is dan de opgegeven verdeling.

${ }^{45}$ Zie Hurwicz (1972).
} 
ingevuld te hebben. Helass zijn wij Aumann niet.

\section{TOT SLOT}

Tot slot wil ik eerst mijn 29 wetenschappelijke co-auteurs bedanken. Ongetwijfeld hebben zij bijgedragen aan de verhoging van mijn Erdös-getal, maar u mag hier ook een andere naam invullen. Mijn belangrijkste co-auteur is Stef Tijs, van wie ik zeer veel geleerd heb, onder andere dat je je moet beperken, lees: aan het werk moet, om iets te bereiken.

Ik beschouw deze inaugurale rede als een dubbele. In juni jongstleden zijn Koos Vrieze en ik benoemd tot Honorar Professor aan de Rheinisch-Westfälische Technische Hochschule in Aken. Achteraf kan ik zeggen dat ik met deze rede zolang (bijna vijf jaren) gewacht heb totdat ook die aanstelling rond was. Ook voor de Universiteit Maastricht, die-onder meer middels het ALMA-verdrag-internationalisering hoog in haar vaandel geschreven heeft, is dit een mooi resultaat.

Voorts wil ik mijn ouders bedanken, die net hun vijftigjarig huwelijk gevierd hebben. Zij zijn er in de eerste plaats voor verantwoordelijk dat ik hier sta, en dat in meer dan één opzicht.

Veel méér dan dank gaat uit naar Lenie. Dat is een vanzelfsprekendheid die, desondanks, af en toe uitgesproken moet worden.

Ik heb gezegd. 


\section{Literatuur}

Akerlof, G. (1970): "The market for Lemons," Quarterly Journal of Economics, 84, 488-500.

Allais, M. (1953): "Fondements d'une Théorie Positive des Choix Comportant un Risque et Critique des Postulats et Axiomes de l'Ecole Américaine," Colloques Interna. tionaux du Centre National de la Recherche Scientifique, 40, Econométrie, 257-332. Paris: Centre National de la Recherche Scientifique.

Arrow, K.J. (1951): Social Choice and Individual Values. New York: John Wiley.

Banker, R.D., A. Charnes, W.W. Cooper, \& R. Clarke (1989): "Constrained Game Formulations and Interpretations for Data Envelopment Analysis," European Journal of Operational Research, 40, 299-308.

Bernheim, B.D. (1984): "Rationalizable Strategic Behavior," Econometrica, 52, 10071029.

Binmore, K., and P. Dasgupta (1987): The Economics of Bargaining. Oxford, UK: Basil Blackwell.

Black, D. (1969): "Lewis Carroll and the Theory of Games," American Economic Review, Proceedings.

Borel, E. (1927): "Sur les Systèmes de Formes Linéaires à Déterminant Symmétrique Gauche et la Théorie Générale du Jeu," Comptes Rendus de l'Académie des Sciences, 184, 52-53. Translated by L.J. Savage (1953): "On Systems of Linear Forms of Skew Symmetric Determinant and the General Theory of Play," Econometrica, 21, 116-117.

Borel, E. (1938): Applications des Jeux de Hasand Tome 4, fascicle 2 of Thaite du Calcul des Probabilités et de ses Applications, rédigé par Jean Ville, Paris: GauthierVillars.

Clarke, E. (1971): "Multipart Pricing of Public Goods," Public Choice, 11, 17-33.

Cournot, A.A. (1838): Recherches sur les Principes Mathématiques de la Théorie des Richesses. Paris: Librairie des Sciences Politiques et Socisles, M. Rivière \& Cie. Translated by N.T. Bacon $(1897,1927)$ : Researches into the Mathematical Principles of the Theory of Wealth New York: Macrnillan.

Dantzig, G.B. (1951): "Maximization of Linear Functions of Variables Subject to Linear Inequalities," in T.C. Koopmans (ed.): Activity Analysis of Production and Allocation, 339-347. New York: John Wiley \& Sons, Inc.

Delver, R., and H. Monsuur (1997): "Towards a Theory of Domination," Report R.N. Naval Acaderny.

Dimand, M.A., \& R.W. Dimand (1996): The History of Game Theory, Volume 1. London: Routledge.

Dodgson, C.L. (1884): The Principles of Parliamentary Presentation. London: Harrison \& Sons

Dresher, M. L.S. Shapley, \& A.W. Tucker, eds. (1964): Advances in Games Theory. Annals of Mathematics Studies, 52. Princeton NJ: Princeton University Press. 
Dresher, M., A.W. Tucker, \& P. Wolfe, eds. (1957): Contributions to the Theory of Games III. Annals of Mathematics Studies, 39. Princeton NJ: Princoton University Press.

Edgeworth, F.Y. (1881): Mathematical Psychics. London: Paul Kegan.

Ellickson, B. (1993): Competitive Equilibrium: Theory and Applications. Cambridge UK: Cambridge University Press.

Gibbard, A. (1973): "Manjpulation of Voting Schemes: A General Result", Econometrica, 41, 587-601.

Gillies, D.B. (1953): Some Theorems on n-person Games. Ph.D. Thesis. Princeton, New - Jersey: Princeton University Press.

Groves, T. (1973): "Incentives in Teams," Econometrica, 41, 617-631.

Gul, F. (1989): "Bargaining Foundations of Shapley Value," Econometrica, 57, 81-95.

Harsanyi, J.C. (1967, 1968): "Games with Incomplete Information played by "Bayesian" Players," I, II, and III, Management Science, 14, 159-182, 320-334, 486-502.

Hart, S., \& A. Mas-Colell (1996): "Bargaining and Value," Econometrica, 64, 357-380.

Herstein, I.N., \& J. Milnor (1953): "An Axiomatic Approach to Measurable Utility," Econometrica, 21, 291-297.

Hurwicz, L. (1972): "On Informationally Decentralized Systems," in R. Radner and B. McGuire, eds., Decision and Onganization, 297-336. Amsterdam: North-Holland.

Kahneman, D., \& A. Tversky (1979): "Prospect Theory: An Analysis of Decision under Risk," Econometrica, 47, 263-291.

Kohberg, E., \& J.-F. Mertens (1986): "On the Strategic Stability of Equilibria," Econometrica, 54, 1003-1039.

Kreps, D.M., \& R. Wilson (1982): "Sequential Equilibria," Econometrica, 50, 863-894.

Kuhn, H.W, \& A.W. Tucker, eds. (1950): Contributions to the Theory of Games I. Annals of Mathematics Studies, 24. Princeton NJ: Princeton University Press.

Kuhn, H.W., \& A.W. Tucker, eds. (1953): Contributions to the Theory of Games II. Annals of Mathematics Studies, 28. Princeton NJ: Princeton University Press.

Lakatos, I. (1976): Proofs and Refutations: The Logic of Mathematical Discovery. Edited by J. Worrall \& E. Zahar. Cambridge, UK: Cambridge University Press.

Lucas, W.F. (1969): "The Proof that a Game May Not Have a Solution," Trans. Am. Math. Soc., 136, 219-229.

Luce, R.D., \& A.W. Tucker, eds. (1959): Contributions to the Theory of Games IV. Annals of Mathematics Studies, 40. Princeton NJ: Princeton University Press.

McDonald, I.M., and R.M. Solow (1981): "Wage Bargaining and Employment", American Economic Review, 71, 896-908.

McLean, I., A. McMillan, \& B.L. Monroe, eds. (1996): A Mathematical Approach to Proportional Representation: Duncan Black on Lewis Carrolh Dordrecht: Kluwer Academic Publishers. 
Mertens, J.F., and S. Zamir (1985): "Formulation of Bayesian Analysis for Games with Incomplete Information,", International Journal of Game Theory, 14, 1-29.

Moulin, H. (1980): "On Strategy-Proofness and Single Peakedness," Public Choice, 35, 437-455.

Nash, J.F. (1950): "The Bargaining Problem," Econometrica, 18, 155-162.

Nash, J.F. (1951): "Non-Cooperative Games," Annals of Mathematics, 54, 286-295.

Nash, J.F. (1953): "Two-Person Cooperative Games," Econometrica, 21, 128-140.

Pareto, V. (1907): Manuel d'Economie Politique. Paris.

Pearce, D.G. (1984): "Rationalizable Strategic Behavior and the Problem of Perfection," Econometrica, 52, 1029-1051.

Peters, H. (1992): Ariomatic Bargaining Game Theory. Dordrecht: Kluwer Academic Publishers.

Peters, H., \& K. Vrieze (1993): A Course in Game Theory. Aachener Beiträge zur Mathernatik, Band 6. Aachen: Verlag der Augustinus Buchhandlung.

Ross, S.A. (1977): "The Determination of Financial Structure: The Incentive Signaling Approach," Bell Journal of Economics, 40, 23-40.

Rubinstein, A. (1982): "Perfect Equilibrium in a Bargaining Model," Econometrica, 50, 97-109.

Satterthwaite, M. (1975): "Strategy-Proofness and Arrow's Conditions: Existence and Correspondence Theorem for Voting Procedures and Social Choice Functions," Journal of Economic Theory, 10, 187-217.

Selten, R. (1965): "Spieltheoretische Behandlung eines Oligopolmodels mit Nachfragezeit," Zeitschrift fir Gesammte Staatswissenschafh, 121, 301-324.

Selten, R. (1975): "Reexamination of the Perfectness Concept for Equilibrium Points in Extensive Games," International Journal of Game Theory, 4, 25-55.

Shapley, L.S. (1953): "A Value for n-Person Games". In: A.W. Tucker, H.W. Kuhn (eds.), Contributions to the Theory of Games $I I, 307-317$. Princeton, New Jersey: Princeton University Press.

Spence, M. (1973): "Job Market Signaling," Quarterly Journal of Economics, 87, 355-374.

Sun Tzu (1988): The Art of Wor. Translated by T. Cleary. Boston and Shaftesbury, Dorset: Shambhala.

Thakor, A.V. (1991): "Game Theory in Finance," Financial Management, 71-94.

van Damme, E. (1991): Stability and Perfection of Nash Equilibria. Berlin Heidelberg: Springer-Verlag.

Vickrey, W. (1961): "Counterspeculation, Auctions and Competitive Sealed Tenders," Journal of Finance, 16, 8-37.

von Neumann, J. (1928): "Zur Theorie der Gesellschaftsspiele," Mathematische Annalen, $100,295-320$. 
von Neumann, J., \& O. Morgenstern (1944): Theory of Games and Economic Behavior. Princeton: Princeton University Press.

yon Neumann, J., \& O. Morgenstern (1947): Theory of Games and Economic Behavior. Princeton: Princeton University Press, 2nd edition. First Princeton Paperback printing: 1980.

von Stackelberg, H.F. (1934): Morktform und Gleichgewicht. Wien: Julius Springer.

Zermelo, E. (1913): "Über eine Anwendung der Mengenlehre auf die Theorie des Schachspiels," Proceedings Fifth International Congress of Mathematicians, 2, 501-504. 